\title{
COOPERATION WITHIN PHYSICIAN-NURSE TEAM IN OCCUPATIONAL MEDICINE SERVICE IN POLAND - KNOWLEDGE ABOUT PROFESSIONAL ACTIVITIES PERFORMED BY THE TEAM-PARTNER
}

\author{
WSPÓŁPRACA W ZESPOLE LEKARZ-PIELĘGNIARKA W SŁUŻBIE MEDYCYNY PRACY W POLSCE - \\ WIEDZA O ZADANIACH WYKONYWANYCH PRZEZ PARTNERA Z ZESPOŁU
}

Nofer Institute of Occupational Medicine / Instytut Medycyny Pracy im. prof. J. Nofera, Łódź, Poland

Health Policy Department / Zakład Polityki Zdrowotnej

\begin{abstract}
Background: The goal of the study has been to learn about physicians' and nurses' awareness of the professional activities that are being performed by their colleague in the physician-nurse team. Material and Methods: Postal questionnaires were sent out to occupational physicians and nurses in Poland. The analysis includes responses from 232 pairs of physician-nurse teams. Results: The knowledge among occupational professionals about tasks performed by their colleagues in the physician-nurse team seems to be poor. Respondents were asked about who performs tasks from each of 21 groups mentioned in the Occupational Medicine Service Act. In the case of only 3 out of 21 groups of tasks, the rate of non-consistence in answers was lower than $30 \%$. A specified number of professionals performed their tasks on the individual basis. Although in many cases their team colleagues knew about those activities, there was a major proportion of those who had no awareness of such actions. Conclusions: Polish occupational physicians and nurses perform a variety of tasks. Occupational nurses, besides medical role, also play important organizational roles in their units. The cooperation between the two professional groups is, however, slightly disturbed by the deficits in communication. This issue needs to be improved for the betterment of operations within the whole system. Med Pr 2015;66(5):625-633
\end{abstract}

Key words: occupational medicine, interpersonal communication, occupational health nursing, occupational nurse, occupational physician, occupational health care

\section{STRESZCZENIE}

Wstęp: Celem badania było zdobycie wiedzy na temat świadomości lekarzy i pielęgniarek medycyny pracy w zakresie zadań zawodowych wykonywanych przez kolegów/koleżanki z zespołów tworzonych przez lekarza i pielęgniarkę służby medycyny pracy (SMP). Material i metody: Badanie przeprowadzono z wykorzystaniem ankiety pocztowej rozesłanej do jednostek SMP z terenu Polski, w których pracują zespoły lekarz-pielęgniarka. Analiza uwzględnia odpowiedzi przesłane przez 232 zespoły lekarz-pielęgniarka. Wyniki: Wiedza na temat zadań wykonywanych w ramach tego samego zespołu przez kolegów/koleżanki wydaje się niewielka. Respondentów poproszono o wskazanie osób wykonujących w ramach zespołu lekarz-pielęgniarka zadania SMP wymienione w ustawie o służbie medycyny pracy. W przypadku zaledwie 3 spośród 21 grup zadań rozbieżność odpowiedzi nie przekraczała $30 \%$. Niektóre zadania są wykonywane przez profesjonalistów bez udziału innych osób. Duża część ankietowanych wykazywała niewiedzę na temat zadań wykonywanych przez partnera z zespołu. Wnioski: Lekarze i pielęgniarki medycyny pracy w Polsce wykonują zróżnicowane zadania. Pielęgniarki, oprócz zadań typowo medycznych, pełnią w swoich jednostkach także ważne funkcje organizacyjne. Należy zauważyć, że współpraca między tymi dwoma grupami zawodowymi w ramach systemu ochrony zdrowia pracujących jest w pewnym stopniu zakłócana przez niewystarczającą komunikację interpersonalną. Należy dążyć do poprawy w tym obszarze w celu poprawy funkcjonowania całego systemu służby medycyny pracy. Med. Pr. 2015;66(5):625-633

Słowa kluczowe: medycyna pracy, komunikacja interpersonalna, pielęgniarstwo w ochronie zdrowia pracujących, pielęgniarka medycyny pracy, lekarz medycyny pracy, ochrona zdrowia pracujących

Corresponding author / Autor do korespondencji: Piotr Sakowski, Nofer Institute of Occupational Medicine, Health Policy Department, św. Teresy 8, 91-348 Łódź, Poland, e-mail: psak@imp.lodz.pl Received: October 17, 2014, accepted: July 24, 2015

Funding / Finansowanie: the study has been carried out under the project IMP 8.1/2011 "Analysis of cooperation between occupational physicians and nurses in the Polish system of occupational medicine service." Project coordinator: Piotr Sakowski, MPH. 


\section{INTRODUCTION}

The Polish system of occupational medicine is focused on medical aspects of occupational health protection. According to the law [1] the occupational medicine service in Poland is comprised of multidisciplinary personnel, however, in practice they are mainly physicians, nurses as well as several psychologists.

In health care systems in general (the occupational health care system being a sub-system) there are several items, sub-cultures according to Shortell et al., which influence achieving goals of the organization (a health care unit) due to the fact that different sub-cultures may have different goals within the departments or units of the facility [2]. Among those sub-cultures professional group cultures are mentioned [2]. Shortell et al. claim that for providing good health care to patients, the cooperation with all members of a team is necessary and physicians cannot be the only individuals responsible for patients [3]. Savic and Pagon claim that good cooperation between nurses and physicians is "of strategic importance for high quality patient care" and for "positive work environment for both groups of health professionals" [4]. Taking into account that those professionals, who are the main stakeholders in the Polish occupational health system, work together for the benefit of their patients (i.e. employees), the level of their cooperation is crucial for proper operations of that system.

Another research has shown that - according to Polish occupational nurses - there are areas of professional life related to the cooperation with occupational physicians, which need improvement - only one out of three nurses has been satisfied with the quality of the cooperation with physicians, on the other hand almost $15 \%$ of nurses have been highly dissatisfied and the rest of them have noticed areas for action to make the cooperation better [5-7].

This paper presents results of the survey that aimed at learning about the cooperation between occupational physicians and nurses in Poland - the scope of such cooperation, its strengths and weaknesses. To be more specific - it presents results concerning physicians' and nurses' awareness of the professional activities that are being performed by their colleagues in the physician-nurse team.

\section{MATERIAL AND METHODS}

The survey was carried out in the second half of 2011, with the use of postal questionnaires, among the population of occupational physicians and nurses in Poland.
The questionnaire used in the survey contained a series of questions related with the physician-nurse cooperation, taking into account such aspects as the type of the occupational medicine service (OMS) unit, form of employment of respondents, and of course - the cooperation. Based on the Occupational Medicine Service Act [1], which precisely lists tasks of the occupational medicine service, the questionnaire had been designed to learn who - in the opinion of respondents - performed each of the tasks in their OMS units (a physician, nurse, someone else, nobody). According to the OMS Act [1], the tasks are presented below [translator: the self-made translation from the Polish version of the act of law]. It bears noting that the task numbering in the following list corresponds with the numbering of the tasks in each of the 3 tables presented in this article:

1. The cooperation with an employer in processes of identification and assessment of factors found in the work environment and methods of performing job that may have a negative health impact.

2. The cooperation with employers in processes of identification and assessment of occupational risk in the work environment and providing information to employers and employees concerning possible adverse health effects arising from such a risk.

3. Providing advice to employers and employees concerning work organization, ergonomics, physiology and psychology of work.

4. Performing pre-employment, periodic and control medical examinations described in the Labor Code Act [8].

5. Medical certification for the purposes of the Labor Code Act and other related laws.

6. Assessment of the ability to perform work or study taking into account health status and threats existing at the workplace or study place.

7. Consultation, diagnostics and medical certification in the field of occupational pathology.

8. Providing advices for those who suffer from occupational or work related diseases.

9. Performing prophylactic vaccinations described in the article 20 of the Act of 5 December 2008 on the prevention and fighting infections and infectious diseases in people [9].

10. Health status monitoring among employees in groups of special risk, particularly those who work in conditions of exceeded hygienic norms, juveniles, the disabled, women of reproductive age and pregnant women.

11. Performing examinations allowing for early diagnostics of occupational and work-related diseases. 
12. Performing outpatient curative rehabilitation justified by certified occupational pathology.

13. Organization of and providing first aid in acute cases of illness and accidents at work, places of duty or study.

14. Initiation and realization of health promotion, particularly prophylactic health programs resulting from employees' health status assessment.

15. Initiation of employers' actions aimed at occupational health protection and providing support in their realization in the field of providing information for employees concerning occupational risk mitigation measures.

16. Initiation of employers' actions aimed at occupational health protection and providing support in their realization in the field of implementation of the health prophylactic policy for employees in the special risk groups.

17. Initiation of employers' actions aimed at occupational health protection and providing support in their realization in the field of creating conditions for performance of occupational rehabilitation.

18. Initiation of employers' actions aimed at occupational health protection and providing support in their realization in the field of implementation of health promotion programs.

19. Initiation of employers' actions aimed at occupational health protection and providing support in their realization in the field of providing first premedical aid.

20. Conducting analyses of employees' health status, particularly occurrence of occupational diseases and their causes, and causes of occupational accidents.

21. Gathering, keeping and processing information concerning occupational exposure, occupational risk, and health status of those who are covered by prophylactic health care.

The questionnaire was sent to OMS units together with a cover letter informing about the purpose of the study, how to complete the questionnaire form and what to do afterwards, and also emphasizing the anonymous nature of the study. Units for the study were chosen with the use of available contact details. On the basis of the Polish legislation concerning public statistics [10] the data related with structure and activities of occupational medicine service was collected. That data, however, was not always complete and only served the purposes of estimating the number of units with a physician-nurse team in their organizational structures. For the purposes of the survey the list of all such units was created, multiple entries were deleted, which resulted in effective delivery of questionnaires to almost 900 occupational medicine service units.

Questionnaires were sent to 873 occupational medicine units (a basic organizational entity in the Polish OMS system) which had in its structure at least one physician and cooperating nurse (according to the latest available data from the national mandatory reports). The response rate was $43.3 \%$ (questionnaires were sent back by 378 units), which was similar to response rates in other postal-questionnaire-based studies conducted by the research team for the population of occupational health professionals in Poland. Taking into account characteristics of the study population (similar, close to the same, professional background and professional goals), the obtained response rate was good enough for drawing conclusions. From all returned questionnaires, taking into account completeness of provided information, responses from 232 pairs of physician-nurse teams were selected, coded and qualified for the analysis. What is important from the point of view of interpretation of the results, concordance/discordance of replies was analyzed for individual pairs of professionals working in the same OMS unit as a team (yet, keeping the anonymity of analyzed data). Replies given by a physician and a nurse from the same team were compared taking into account their coherence.

\section{RESULTS}

The results show that the knowledge among occupational physicians and nurses about tasks performed by their colleagues in the physician-nurse team is poor. The research team asked both physicians and nurses about who performed tasks included in the OMS Act. In the case of only 3 out of 21 tasks, the rate of non-consistence in answers (consistence is understood in a way that both professionals from the pair have provided the same reply to each question) was lower than $30 \%$ (tasks No. 1 , 5 and 6) - i.e., less than $30 \%$ of physician-nurse pairs provided coherent answers about an executor of the task concerned. In the case of 3 groups of tasks, the rate of which was higher than $40 \%$, there was one case of almost 50\% (tasks 14, 18 and 19). The mean value of the non-consistence rate was at the level of $35.9 \%$ (standard deviation $(\mathrm{SD})=6$ ) meaning that on average more than one out of three physician-nurse teams gave incoherent answers. Detailed results of difference in replies to the question "Who performs each task in your occupational medicine service unit?" are shown in the Table 1. 
Table 1. Nature of answers (consistent/not consistent) given by physician-nurse teams to the question: "Who performs each task in your occupational medicine service unit?"

Tabela 1. Zbieżność odpowiedzi udzielonych przez członków zespołu lekarz-pielęgniarka na pytanie „Kto wykonuje poszczególne zadania w Państwa jednostce służby medycyny pracy?”

Respondents

Respondenci

Task

Zadanie
$(\mathrm{N}=232)$

[n (\%)]

consistent answers odpowiedzi zbieżne

$172(74.1)$

not consistent answer odpowiedzi rozbieżne

1. Cooperation with an employer in processes of identification and assessment of factors found in the work environment and methods of performing a job that may have a negative health impact / / Współdziałanie z pracodawcą w procesach rozpoznawania i oceny czynników występujących w środowisku pracy oraz sposobów wykonywania pracy mogących mieć ujemny wpływ na zdrowie

2. Cooperation with employers in processes of identification and assessment of occupational risk in the work environment and transmission of information to employers and employees concerning possible adverse health effects arising from such a risk / Współdziałanie z pracodawcą $\mathrm{w}$ procesach rozpoznawania i oceny ryzyka zawodowego w środowisku pracy oraz informowanie pracodawców i pracujących o możliwości wystąpienia niekorzystnych skutków zdrowotnych będących jego następstwem

3. Providing advice to employers and employees concerning work organization, ergonomics, physiology and psychology of work / Udzielanie pracodawcom i pracującym porad w zakresie organizacji pracy, ergonomii, fizjologii i psychologii pracy

4. Performing pre-employment, periodic and control medical examinations described in the Labor Code Act / Wykonywanie badań wstępnych, okresowych i kontrolnych przewidzianych w Kodeksie pracy $[8]$

5. Medical certification for the purposes of the Labor Code Act and other related laws / Orzecznictwo lekarskie do celów przewidzianych w Kodeksie pracy i przepisach wydanych na jego podstawie

6. Assessment of ability to perform work or study taking into account health status and threats existing at the workplace or study place / Ocena możliwości wykonywania pracy lub pobierania nauki uwzględniająca stan zdrowia i zagrożenia występujące w miejscu pracy lub nauki

7. Consultation, diagnostics and medical certification in the field of occupational pathology / / Prowadzenie działalności konsultacyjnej, diagnostycznej i orzeczniczej w zakresie patologii zawodowej

8. Providing advice for those who suffer from occupational or work related diseases / Prowadzenie czynnego poradnictwa w stosunku do chorych na choroby zawodowe lub inne choroby związane $\mathrm{z}$ wykonywaną pracą

9. Performing prophylactic vaccinations described in the article 20 of the Act of 5 December 2008 on the prevention and fighting infections and infectious diseases in people / Wykonywanie szczepień ochronnych, o których mowa w art. 20 Ustawy z dnia 5 grudnia 2008 r. o zapobieganiu oraz zwalczaniu zakażeń i chorób zakaźnych u ludzi [9]

10. Health status monitoring among employees in groups of special risk, particularly those who work in conditions of exceeded hygienic norms, juveniles, the disabled, women of reproductive age and pregnant women / Monitorowanie stanu zdrowia osób pracujących zaliczanych do grup szczególnego ryzyka, zwłaszcza osób wykonujących pracę w warunkach przekroczenia normatywów higienicznych, młodocianych, niepełnosprawnych oraz kobiet $\mathrm{w}$ wieku rozrodczym i ciężarnych

11. Performing examinations allowing for early diagnostics of occupational and work-related diseases / / Wykonywanie badań umożliwiających wczesną diagnostykę chorób zawodowych i innych chorób związanych z wykonywaną pracą

12. Performing outpatient curative rehabilitation justified by certified occupational pathology / / Prowadzenie ambulatoryjnej rehabilitacji leczniczej uzasadnionej stwierdzoną patologią zawodową

Organization and providing first aid in acute cases of illness and accidents at work, the place of duty or study / Organizowanie i udzielanie pierwszej pomocy medycznej w nagłych zachorowaniach i wypadkach, które wystąpiły w miejscu pracy, służby lub pobierania nauki 
Table 1. Nature of answers (consistent/not consistent) given by physician-nurse teams to the question:

"Who performs each task in your occupational medicine service unit?" - cont.

Tabela 1. Zbieżność odpowiedzi udzielonych przez członków zespołu lekarz-pielęgniarka na pytanie „Kto wykonuje poszczególne zadania w Państwa jednostce służby medycyny pracy?” - cd.

Respondents

Respondenci

Task

Zadanie
$(\mathrm{N}=232)$

[n (\%)] consistent answers odpowiedzi zbieżne not consistent answers odpowiedzi rozbieżne
14. Initiation and realization of health promotion, particularly prophylactic health programs resulting from employees' health status assessment / Inicjowanie i realizowanie promocji zdrowia, zwłaszcza profilaktycznych programów prozdrowotnych, wynikających z oceny stanu zdrowia pracujących

15. Initiation of employers' actions aimed at occupational health protection and providing support in their realization in the field of providing information for employees concerning occupational risk mitigation measures / Inicjowanie działań pracodawców na rzecz ochrony zdrowia pracowników i udzielanie pomocy w ich realizacji w zakresie informowania pracowników o zasadach zmniejszania ryzyka zawodowego

16. Initiation of employers' actions aimed at occupational health protection and providing support in their realization in the field of implementation of the health prophylactic policy for employees in the special risk groups / Inicjowanie działań pracodawców na rzecz ochrony zdrowia pracowników i udzielanie pomocy w ich realizacji w zakresie wdrażania zasad profilaktyki zdrowotnej u pracowników należących do grup szczególnego ryzyka

17. Initiation of employers' actions aimed at occupational health protection and providing support in their realization in the field of creating conditions to perform occupational rehabilitation / / Inicjowanie działań pracodawców na rzecz ochrony zdrowia pracowników i udzielanie pomocy w ich realizacji w zakresie tworzenia warunków do prowadzenia rehabilitacji zawodowej

18. Initiation of employers' actions aimed at occupational health protection and providing support in their realization in the field of implementation of health promotion programs / Inicjowanie działań pracodawców na rzecz ochrony zdrowia pracowników i udzielanie pomocy w ich realizacji w zakresie wdrażania programów promocji zdrowia

19. Initiation of employers' actions aimed at occupational health protection and providing support in their realization in the field of providing first pre-medical aid / Inicjowanie działan pracodawców na rzecz ochrony zdrowia pracowników i udzielanie pomocy w ich realizacji w zakresie organizowania pierwszej pomocy przedmedycznej

20. Performing analyses of employees' health status, particularly occurrence of occupational diseases and their causes, and causes of occupational accidents / Prowadzenie analiz stanu zdrowia pracowników, zwłaszcza występowania chorób zawodowych i ich przyczyn oraz przyczyn wypadków przy pracy

21. Gathering, keeping and processing information concerning occupational exposure, occupational risk, and health status of those who are covered by prophylactic health care / Gromadzenie, przechowywanie i przetwarzanie informacji o narażeniu zawodowym, ryzyku zawodowym i stanie zdrowia osób objętych profilaktyczną opieką zdrowotną

$136(58.6)$

$96(41.4)$

$144(62.1)$

$88(37.9)$

A specified number of physicians and nurses performed their tasks on the individual basis. Although in many cases their team colleagues knew about those activities, there was a major proportion of those who had no awareness of such actions. Tables 2 and 3 show divergence in knowledge about individual tasks performed within the team. In order to show the level of unawareness, the research team presented divergence by calculating the difference in the number of physi- cian-nurse pairs providing coherent answers (i.e. those who knew about tasks being performed by the teammate) and relating it to the actual number of physicians (or nurses - depending on the question given and profession of a respondent) who declared performance of a specific task. It is worth noticing that in the case of only two groups of tasks, less than $10 \%$ of nurses were not aware that those tasks were being performed by their colleagues in the team, and in the case of 7 out 
of 21 task groups, more than $40 \%$ of nurses presented unawareness. The mean value of the awareness divergence percentage was at the level of $29.2 \%$ ( $S D=18$ ). The situation in the case of physicians was even worse. The smallest rate of physicians who were not aware that a nurse from their team performed a specific task

Table 2. Physicians who declare to have performed specific tasks vs. knowledge of that fact among team-partner nurses

Tabela 2. Lekarze deklarujący wykonywanie poszczególnych zadań vs wiedza o tym zgłaszana przez pielęgniarki z zespołu

\begin{tabular}{|c|c|c|c|}
\hline \multirow[b]{2}{*}{$\begin{array}{c}\text { No. } \\
\text { of task } \\
\mathrm{Nr} \\
\text { zadania }^{*}\end{array}$} & \multicolumn{2}{|c|}{$\begin{array}{c}\text { Respondents } \\
\text { Respondenci } \\
\quad(\mathrm{N}=232)\end{array}$} & \multirow[b]{2}{*}{$\begin{array}{c}\text { Awareness } \\
\text { divergence } \\
\text { Rozbieżność } \\
\left(\left[\left(\mathrm{n}_{1}-\mathrm{n}_{2}\right) / \mathrm{n}_{1}\right] \times 100 \%\right) \\
{[\%]}\end{array}$} \\
\hline & $\begin{array}{c}\text { physicians } \\
\text { performing } \\
\text { specific tasks } \\
\text { on the individual } \\
\text { basis } \\
\text { lekarze } \\
\text { deklarujący } \\
\text { wykonywanie } \\
\text { danych zadan } \\
{\left[\mathrm{n}_{1}\right]}\end{array}$ & $\begin{array}{c}\text { nurses } \\
\text { who knew about } \\
\text { performance } \\
\text { of those tasks } \\
\text { by physicians } \\
\text { pielęgniarki } \\
\text { twierdzące, } \\
\text { że wiedzą } \\
\text { o zadaniach } \\
\text { wykonywanych } \\
\text { przez lekarza } \\
{\left[\mathrm{n}_{2}\right]}\end{array}$ & \\
\hline 1 & 55 & 45 & 18.2 \\
\hline 2 & 59 & 48 & 18.7 \\
\hline 3 & 75 & 44 & 41.3 \\
\hline 4 & 105 & 69 & 34.3 \\
\hline 5 & 196 & 183 & 6.6 \\
\hline 6 & 148 & 133 & 10.1 \\
\hline 7 & 114 & 106 & 7.0 \\
\hline 8 & 79 & 65 & 17.7 \\
\hline 9 & 22 & 6 & 63.6 \\
\hline 10 & 54 & 48 & 11.1 \\
\hline 11 & 89 & 66 & 25.8 \\
\hline 12 & 22 & 17 & 22.7 \\
\hline 13 & 25 & 13 & 48.0 \\
\hline 14 & 36 & 13 & 63.9 \\
\hline 15 & 44 & 32 & 27.3 \\
\hline 16 & 56 & 42 & 25.0 \\
\hline 17 & 26 & 22 & 15.4 \\
\hline 18 & 35 & 19 & 45.7 \\
\hline 19 & 45 & 21 & 53.3 \\
\hline 20 & 64 & 55 & 14.1 \\
\hline 21 & 42 & 24 & 42.9 \\
\hline
\end{tabular}

* Task descriptions as in Table 1 / Opisy zadań jak w tabeli 1. exceeded $27 \%$. In the case of 8 task groups, the percentage rate was over $50 \%$, which proved that in general physicians knew very little about what nurses from their professional team did. The mean value of the awareness divergence percentage was in that case at the level of 51.2\% (SD = 19.7).

Table 3. Nurses who declare to have performed specific tasks vs. knowledge of that fact among team-partner physicians

Tabela 3. Pielęgniarki deklarujące wykonywanie poszczególnych zadań vs wiedza o tym zgłaszana przez lekarzy z zespołu

\begin{tabular}{|c|c|c|c|}
\hline \multirow[b]{2}{*}{$\begin{array}{c}\text { No. } \\
\text { of task } \\
\text { Nr } \\
\text { zadania* }^{*}\end{array}$} & \multicolumn{2}{|c|}{$\begin{array}{l}\text { Respondents } \\
\text { Respondenci } \\
\quad(\mathrm{N}=232)\end{array}$} & \multirow[b]{2}{*}{$\begin{array}{c}\text { Awareness } \\
\text { divergence } \\
\text { Rozbieżność } \\
\left(\left[\left(\mathrm{n}_{1}-\mathrm{n}_{2}\right) / \mathrm{n}_{1}\right] \times 100 \%\right) \\
{[\%]}\end{array}$} \\
\hline & $\begin{array}{c}\text { nurses } \\
\text { performing } \\
\text { specific tasks } \\
\text { on the } \\
\text { individual basis } \\
\text { pielęgniarki } \\
\text { deklarujące } \\
\text { wykonywanie } \\
\text { danych zadań } \\
{\left[\mathrm{n}_{1}\right]}\end{array}$ & $\begin{array}{c}\text { physicians } \\
\text { who knew about } \\
\text { performance } \\
\text { of those tasks } \\
\text { by nurses } \\
\text { lekarze twierdzący, } \\
\text { że wiedzą } \\
\text { o zadaniach } \\
\text { wykonywanych } \\
\text { przez pielęgniarkę } \\
{\left[\mathrm{n}_{2}\right]}\end{array}$ & \\
\hline 1 & 19 & 11 & 42.1 \\
\hline 2 & 22 & 14 & 27.3 \\
\hline 3 & 22 & 4 & 81.2 \\
\hline 4 & 14 & 4 & 71.4 \\
\hline 5 & 1 & 0 & - \\
\hline 6 & 5 & 2 & - \\
\hline 7 & 1 & 0 & - \\
\hline 8 & 27 & 14 & 48.1 \\
\hline 9 & 95 & 69 & 27.4 \\
\hline 10 & 15 & 10 & 33.3 \\
\hline 11 & 13 & 2 & 84.6 \\
\hline 12 & 5 & 4 & - \\
\hline 13 & 40 & 12 & 70.0 \\
\hline 14 & 75 & 43 & 42.6 \\
\hline 15 & 27 & 10 & 63.0 \\
\hline 16 & 29 & 13 & 55.2 \\
\hline 17 & 17 & 12 & 29.4 \\
\hline 18 & 46 & 33 & 28.3 \\
\hline 19 & 65 & 26 & 60.0 \\
\hline 20 & 17 & 5 & 70.1 \\
\hline 21 & 67 & 43 & 35.8 \\
\hline
\end{tabular}

"-" - too small values to give credible results / zbyt małe wartości, uniemożliwiające podanie wiarygodnych wyników.

* Task descriptions as in Table 1 / Opisy zadań jak w tabeli 1. 
The research team was also curious if there was a relation between the number of areas with discordance in answers in individual physician-nurse pairs and several characteristics of respondents: age of a physician, age of a nurse, tenure of a physician (overall tenure), tenure of a nurse (overall tenure), tenure in the occupational health service (OHS) of a physician, tenure in the OHS of a nurse and finally - age difference between both professionals. Calculations of $\mathrm{Chi}^{2}$ and Person's correlation coefficient showed that in general the relation between the number of areas with incoherent answers was weak and not statistically significant, with one exception. At significance level of at least $\alpha=0.05$, there was weak and statistically significant correlation between the age of a physician and the number of areas with discordance in answers in individual physiciannurse pairs $\left(\mathrm{Chi}^{2}=21.83, \alpha=0.01\right.$, two tailed $\mathrm{p}$-value: 0.0094 , Pearson's correlation coefficient $r=0.1375$ ). The Table 4 presents the results of calculations.

In addition, both groups were asked if they knew anything about other than listed above tasks which were being performed by their co-partner in a team. Among studied pairs, $14.2 \%$ of nurses $(\mathrm{N}=232)$ claimed that they did not know anything about that, and $22.8 \%$ confirmed that they did knew about additional tasks performed by their colleague physician. Those results are close to the replies given by physicians who were asked if they performed any ad- ditional actions, among whom $27.2 \%(\mathrm{~N}=232)$ confirmed such activity. On the other hand, physicians overestimated engagement of nurses in additional activities. In the case of $34.1 \%$ of physicians $(\mathrm{N}=232)$, they assumed that their colleagues, nurses performed additional activities whereas only $25.4 \%(\mathrm{~N}=232)$ of nurses admitted that. Only $5.1 \%$ of physicians admitted that they did not know if their co-worker performed additional tasks.

The survey also provided information concerning typical tasks performed by occupational nurses in their daily routine. Nurses, inter alia, mentioned having taken samples for laboratory tests and performing medical tests $(100 \%, \mathrm{~N}=232)$ : ECG, RR, glucose test, body weight and height measurement, audiometry, spirometry as well as having kept the medical records $(99 \%, \mathrm{~N}=232)$, registration of patients $(72 \%$, $\mathrm{N}=232$ ) and other organizational and administrative activities $(56 \%, \mathrm{~N}=232)$.

\section{DISCUSSION}

Collaboration between healthcare professionals is regarded as an important issue of providing good quality health service [11]. Among several dimensions of collaboration, communication and shared knowledge are issues that are raised [11-13]. Although this is an important factor in creation of good cooperation, infor-

Table 4. Correlations between areas with discordance in answers concerning tasks being performed in the OMS unit within individual physician-nurse teams, and several characteristics of respondents

Tabela 4. Zależność między obszarami z rozbieżnościami w odpowiedziach dotyczących zadań wykonywanych w jednostce SMP w poszczególnych zespołach lekarz-pielęgniarka a wybranymi cechami respondentów

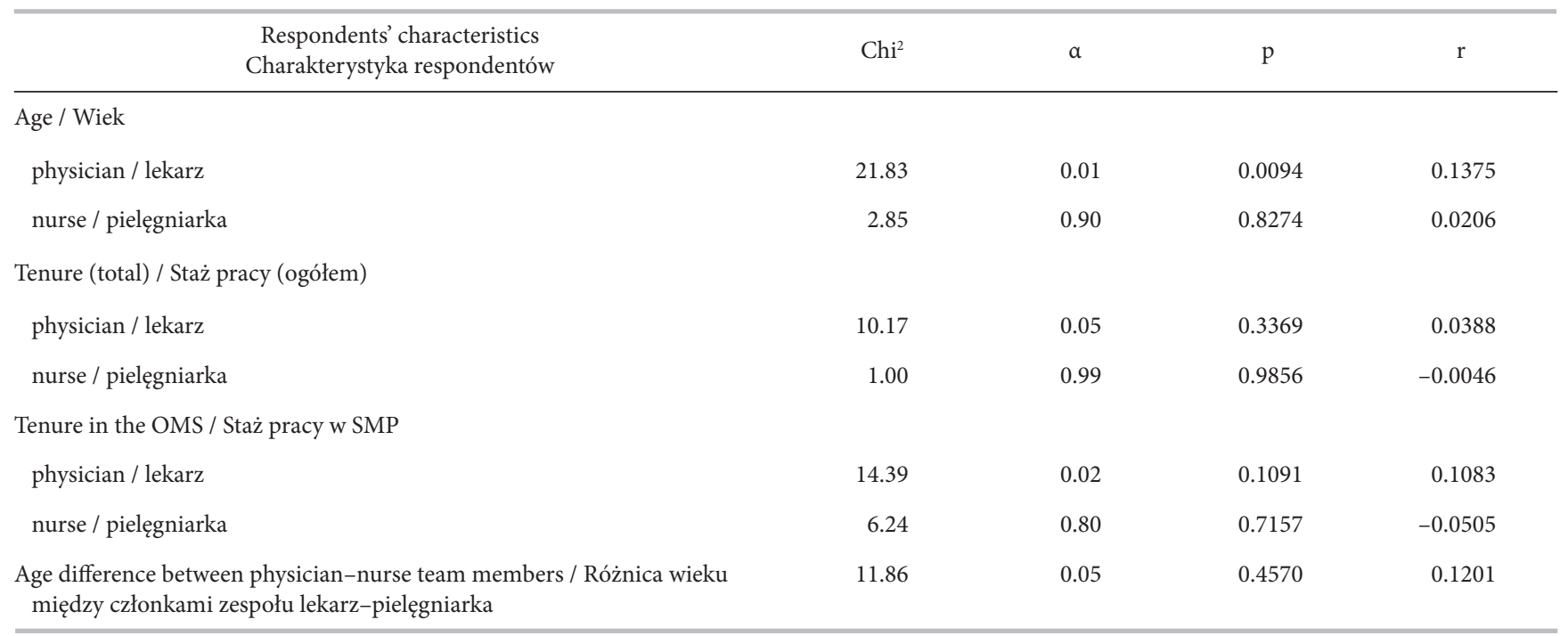

OMS - occupational medicine service / SMP - służba medycyny pracy, Chi ${ }^{2}$ - Chi-square test / test Chi-kwadrat, r - Pearson’s correlation coefficient / współczynnik korelacji Pearsona. 
mation flow and communication among occupational health professionals in Poland have not been yet properly described or studied. The results of the survey show that the knowledge among occupational physicians and nurses about tasks performed by their colleagues in the physician-nurse team is poor. Such knowledge is important for proper, effective operations of OMS units, assuring avoidance of the risk of multiplying activities or the risk of omission of specific actions (which might be more dangerous for patients). From the organizational point of view, effective work organization, utilization of resources within the OMS unit and the whole system in general are also important.

The scarcity of information about assessment of communication between occupational nurses and physicians obstructs references to other studies which concern health care service in general rather than its occupational health-related part. The issues of collaboration, communication problems, communication deficit as well as importance of good communication were noticed in other surveys proving that there was a field for action not only in Polish occupational medicine but in health care systems in general $[4,11,14,15]$.

Results concerning the nurses' daily routine show that Polish occupational nurses perform various tasks of both medical and non-medical nature. The scope of those activities fits into the concept of the role of an occupational nurse described by Whitaker and Baranski [16]. The occupational health nurse is characterized as a multi-skilled professional with capacities to perform clinical and managerial tasks, being a "front liner" in the contact with a patient (an employee).

\section{CONCLUSIONS}

The study has probably been the first one to make an attempt to assess the level and quality of the cooperation between important professional groups operating in the occupational health (medicine) system in Poland. Awareness of the professional activities that are being performed by the colleague in the physician-nurse team is one of prerequisites of smooth operations of each occupational health unit. The conclusions from this study may be twofold:

The study has shown that physicians and nurses in the Polish occupational health system perform variety of tasks. Occupational nurses, besides playing the role in medical procedures, also play an important role in organizational aspects of operations of their units.
The cooperation between the two mentioned professional groups is, however, disturbed by the deficits in communication, which may result in diminished quality of provided services or obstruct smooth operations of an occupational medicine unit (which also may have more or less direct influence on the quality of services). This issue needs to be improved for the betterment of operations of the whole system.

\section{REFERENCES}

1. [The Act of 27 June 1997 on occupational medicine service]. J Laws 1997, No. 96, item 593, with later amendment [cited $2011 \mathrm{Feb} 2$ 2]. Available from: http://isap.sejm.gov. pl/Download;jsessionid=CBAFD3D69FA864406CD805 0896FA2A63?id=WDU19970960593\&type=3. Polish.

2. Shortell SM, Zazzali JL, Burns LR, Alexander JA, Gillies RR, Budetti PP, et al. Implementing evidence-based medicine: The role of the market pressures, compensation incentives, and culture in physicians organizations. Med Care. 2001;39(7 Suppl 1):I62-78, http://dx.doi.org/ 10.1097/00005650-200107001-00005.

3. Shortell SM, Waters TM, Clarke KW, Budetti PP. Physicians as double agents: Maintaining trust in an era of multiple accountabilities. JAMA. 1998;280(12):1102-8, http://dx.doi.org/10.1001/jama.280.12.1102.

4. Savic BS, Pagon M. Relationship between nurses and physicians in terms of organizational culture: Who is responsible for subordination of nurses? Croat Med J. 2008;49: 334-43, http://dx.doi.org/10.3325/cmj.2008.3.334.

5. Sakowski P. [Self-assessment of tasks and roles of occupational medicine service (OMS) nurses in the Polish system of workers' health protection]. Med Pr. 2010;61(5):561-72. Polish.

6. Sakowski P. Job satisfaction of occupational medicine nurses in Poland. Int J Occup Med Environ Health. 2012;25(1): 51-8, http://dx.doi.org/10.2478/s13382-012-0006-x.

7. Sakowski P. [Assessment of the Polish occupational medicine service (OMS) system made by OMS nurses]. Med Pr. 2012;63(1):85-90. Polish.

8. [Labour Code Act as amended of 1974 June 26]. J Laws 1974, No. 24, item 141 [cited 2014 Sep 5]. Available from: http://isap.sejm.gov.pl/Download?id=WDU197402 40141\&type $=3$. Polish

9. [The Act of 5 December 2008 on prevention and fighting infections and infectious diseases in people]. J Laws 2008, No. 234, item 1570, with later amendments [cited 2014 May 15]. Available from: http://isap.sejm.gov. pl/Download?id=WDU20082341570\&type=3. Polish. 
10. [The Act of 29 June 1995 on public statistics]. J Laws 1995, No. 88, item 439, with later amendments [cited 2014 Sep 5]. Available from: http://isap.sejm.gov.pl/Down load?id=WDU19950880439\&type=3. Polish.

11. Ushiro R. Nurse-physician collaboration scale: Development and psychometric testing. J Adv Nurs. 2009;65(7):1497-508, http://dx.doi.org/10.1111/j/1365-26 48.2009.05011.x.

12. Shortell SM, Rousseau DM, Gillies RR, Devers KJ, Simons TL. Organizational assessment in intensive care units (ICUs): Construct development, reliability, and validity of the ICU nurse-physician questionnaire. Med Care. 1991;29(8):709-26, http://dx.doi.org/10.1097/ 00005650-199108000-00004.

13. Lingard L, Espin S, Evans C, Hawryluck L. The rules of the game: Interprofessional collaboration on the inten- sive care unit team. Crit Care. 2004;8(6):R403-8, http:// dx.doi.org/10.1186/cc2958.

14. Bluemel MK, Traweger C, Kinzl JF, Baubin MA, Lederer W. Expectations of patients, nurses and physicians in geriatric nursing home emergencies. J Emerg Med. 2011;28(4):283-6, http://dx.doi.org/10.1136/emj.2010. 093948.

15. Gittell JH, Fairfield KM, Bierbaum B, Head W, Jackson R, Kelly M, et al. Impact of relational coordination on quality of care, postoperative pain and functioning, and length of stay: A nine-hospital study of surgical patients. Med Care. 2000;38(8):807-19, http://dx.doi. org/10.1097/00005650-200008000-00005.

16. Whitaker S, Baranski B, editors. The role of the occupational health nurse in workplace health management. Copenhagen: WHO Regional Office for Europe; 2001.

This work is available in Open Access model and licensed under a Creative Commons Attribution-NonCommercial 3.0 Poland License / Ten utwór jest dostępny w modelu open access na licencji Creative Commons Uznanie autorstwa - Użycie niekomercyjne 3.0 Polska - http://creativecommons.org/ licenses/by-nc/3.0/pl/deed.en. 